\title{
The Contribution of Female Writers in the Libyan Post Arab Spring: The Voice of Azza Al-Maghour's Short Stories
}

\section{Safa El Naili}

To cite this article: El Naili, S. (2019). The Contribution of Female Writers in the Libyan Post Arab Spring: The Voice of Azza Al-Maghour's Short Stories. Al-Raida, 43(1), 1-10.

(C) 2019 The Author(s)

Corresponding author: Safa El Naili

Author contact: safaelnaili@yahoo.com

Article type: Article

Article accepted: $10^{\text {th }}$ August 2019

Published online: 30 ${ }^{\text {th }}$ September 2019

Publisher: Arab Institute for Women

Publication support provided by: Escienta

Journal ISSN: 0259-9953

Copyright: This is an Open Access article, free of all copyright, and may be freely reproduced, distributed, transmitted, modified, built upon, or otherwise used by anyone for any lawful purpose. The work is made available under the Creative Commons Attribution (CC-BY) 4.0 license. 


\title{
The Contribution of Female Writers in Libya Post the Arab Spring: The Voice of Azza Al-Maghour's Short Stories
}

\author{
Safa El Naili
}

The University of Alabama, Burien, The Department of Modern Languages \& Classics, Tuscaloosa, $\mathrm{AL}, \mathrm{USA}$

Abstract

Alongside the rapid political and social change post Arab Spring, Libyan writers were constantly producing volumes of literary work, whether in print or online, to reflect on the sociopolitical issues in the society. Among these writers is Libyan lawyer and writer Azza AlMaghour; Al-Maghour has published a great many short stories during and after the revolution. Using a critical discourse analysis, this paper examines how Al-Maghour contributes to the sociopolitical construction of Libyan society, and argues that Al-Maghour's narrative structure, story frame, language style, and word connotations are used as tools to channel her political views. This paper will pay special attention to Al-Maghour's discussions of women's rights, social justice, and Libyan nationalism through her story settings and her characters. This paper begins by giving a brief overview of the context of Libyan women in the aftermath of the 2011 revolution, followed by Azza Al-Maghour's biography. The paper will then present an analysis of her stories through language, style, story structure, sociopolitical discussions, and her contribution as a Libyan female writer to the context of the post Arab Spring.

Keywords: Libya, Libyan Revolution, Arab Spring, Azza Al-Maghour, short story 
Introduction

In February 2011, Libyans marched the streets demanding the end of a four decades-long dictatorship. The uprising brought radical changes to several institutions. Libyan journalists and activists were driven by nationalistic sentiments to write and express their thoughts during the revolution. Hundreds and hundreds of news reports and columns in local newspapers and online were published. After the downfall of Qaddafi's regime, discussions about the formation of a new state, democracy, and fighting terrorism occupied printed and digital news platforms. However, discussions of human rights, especially women's rights, were, and continue to be, limited.

Despite being legally equal to men in labor and financial independence-such as equal access to promotions and career development opportunities, and equal pay-in practice, Libyan women suffered under Qaddafi's civil rights restrictions, especially in the types of education they could access. They were also excluded from any political or leadership roles. Traditional family law also discriminated against women in areas of child custody, marriage, divorce, and domestic violence. The 2011 revolution, unfortunately, did not bring about any radical change: Although women played a significant role in the revolution-marching in the streets next to men, writing for, and participating in social media platforms, and in some cases actually leading political movements - they were, and still are, underrepresented in official institutions and lack access to leadership roles. Libyan women remain prisoners of tradition and a conservative legal framework couched within a patriarchal society.

Despite the political pressure and the instability accompanying the popular uprising, Libyan elites, journalists, and writers challenged the regime by publishing their news/critical articles and literary texts in local publication houses and online. Most of the literary works produced during the first months of the revolution supported the people's movement and expressed revolutionary sentiments. Some works reflected on Qaddafi's repressive regime. Adaptation to the new reality encouraged authors to write about the fight against social and political injustice (Gheblawi, 2011).

Under Qaddafi's regime writers struggled to express their sociopolitical views freely; their literary works mostly depicted the struggles of the characters without any room for political 
criticism or calls for reform. According to Fagih (2008), the leading character in Libyan short stories is mostly a simple man struggling to survive daily hardship and oppression. Al-Haddad (2010) points out that the image of women in literary works is mostly negative; they are pictured as helpless and suffering from social inequality. The revolution did not change this trend: Literary works in the aftermath of the revolution continued to portray women as helpless victims of social oppression (Elnaili, 2017). Many writers, however, are dedicated to challenging this portrayal of women as weak and vulnerable, especially in the wake of the revolution, which saw the same mass mobilization of women fighting for social justice and equality that was seen across the region. One such writer, Azza Al-Maghour, does exactly this by celebrating the female protagonist in her story, reveling in her strength and positive contribution to the sociopolitical reform of Libya following the Arab Spring.

\section{Azza Al-Maghour: Lawyer, Women's Rights Activist, and Writer}

Azza Al-Maghour is a senior Libyan lawyer who graduated from law school in Benghazi. She studied international law at Sorbonne University, and lectured at the School for Judges in Tripoli in Libya. She was a member of the inaugural committee of the Tripoli Bar Association that issued the first Libyan human rights report in 1998. Among Al-Maghour's accomplishments, she assisted a Libyan detainee in Guantanamo, and she was the first person to address and lecture about HIV positive Libyans in Benghazi. She also addressed feminist issues such as domestic abuse, women's rights, and sexual harassment. Al-Maghour's name is also well recognized in modern Arabic fiction. She has two collections of short stories: Thirty Stories of My City (2013) published by Dar Al Rowad Press in Tripoli, and Fashloum (2012). A number of her stories have been translated into English, such as The Bicycle. She also has a large volume of short stories published online. ${ }^{1}$

Since the Libyan uprising, Al-Maghour has published several political articles and essays discussing the national struggle for freedom, in addition to many short stories. Al-Maghour's stories have an interesting style: She first familiarizes her readers with the place and time through vivid images of the streets and homes. She also describes her characters in critical style, for example, in her story Pepper. In it, she describes the militia leader as a "pepper": Curvy, cheap, and harshly bitter, as a means of demonizing and politically stripping the Libyan militia's power and, at the same time, empowering unarmed citizens. 


\section{Fighting the Political Oppression of Men}

The revolution was destructive. Weapon smugglers helped arm Libyan men, thereby empowering local militias and radical groups. After the fall of Qaddafi's regime, these local militiamen filled the political vacuum and ruled with an iron fist. Al-Maghour's stories highlight the violent rule of these militant groups, and tackled issues that were consistently ignored by the media, especially rape and sexual violence. In The City's Tale, Al-Maghour discusses the sexual assault of a Libyan woman by local militiamen that went viral across social media platforms. The video, andakum wilaya, ${ }^{2}$ stirred anger among the public on social media. However, the assailants were neither identified nor arrested, and the case was soon forgotten, a result of a lack of civil society institutions and a weakened legal framework.

Al-Maghour, however, took a strong stand by openly addressing the rape. She does that by symbolizing the capital city, Tripoli, as a woman who has been violated by forces that lurk in the dark. She associates the decency and dignity of a woman with that of the whole city. With that symbolism, she is indicating that a city is a home, as is a woman in Libyan society, where she is the main pillar in the family. Al-Maghour channels her anger through her writing, criticizing Libyan society for negligence and accusing officials of being bystanders to the violence and chaos that has erupted. She uses the power of her writing to shed light on rape and other forms of violence against women, in order to give Libyan women a voice in a society ruled by men.

The criticism of militias is also seen in her work Pepper. Al-Maghour describes a militia leader as a pepper, a vegetable that is light in weight and sold cheaply in the market. She compares the militiamen to the spicy vegetable which is pungent, hot, and harshly bitter; yet the effect is fleeting and fades quickly. Al-Maghour continues:

Pepper is the cheapest vegetable...all prices go up except for pepper...despite its various, bright colors, it's a cowardly thing because it grows hiding behind the leaves of trees. (2015)

Her comparison emphasizes that despite the harsh and bitter taste of peppers, this harshness fades away instantly, and so does the effect of the militias on the will of women. Their power is weak and their violence is limited and short-lived. 
In Busitta ${ }^{3}$, Al-Maghour (2017e) challenges the sociopolitical views of Libyan men in the aftermath of the revolution. She addresses how the self-identified Rebels of February $17^{\text {th }}$ took advantage of their power to obstruct the peaceful, post-war transition. The greed for authority and control changed the moralities of many of those who were once called heroes. The story is named after a neighborhood in Tripoli that is in the suburbs and lies at the intersection between two big neighborhoods, Zawia Addahmani and Anofileen. Set between these two neighborhoods, Busita references the imbalance between the two other neighborhoods. In the story, Al-Maghour describes how a close family member has turned into a man of power, neglecting family ties and, just like Busitta, he is imbalanced and has no loyalty to the real cause of the revolution. Traditionally, the political role and loyalty of Libyan men should not to be questioned by women. However, Al-Maghour's manifestation of the state's failure post-revolution empowers her as a writer to criticize, discuss, and educate her readers in a time when gun-toting men and the militias they run silence others.

The Role of Women

Al-Maghour imbues her female protagonists with power. At a time when Libyan women were often depicted as weak and marginalized, especially in literary works, Al-Maghour stands out against stereotypes and portrays Libyan women powerfully. For Al-Maghour, women are the foundation of society and, as mothers, create true leaders. In the story Mowgli and Shere Khan, Al-Maghour (2017d) emphasizes the powerful role of mothers in the aftermath of the Arab Spring. Within the context of disarming militias and supporting the national army, she tells the story of two young men who joined the armed revolution against Qaddafi. The first man, named Mowgli, was encouraged by his mother to return to civil life and university: "No more weapons in my house!" his mother implores him. The other man, Shere Khan, a drug dealer, an inmate, and an army deserter, has no family, and crucially, no mother figure to advise him. In this way, Al-Maghour underlines the significant role mothers play in the lives of their children, and the contribution they can make in the aftermath of the Libyan revolution. She demonstrates that women, like men, can play political roles in their families toward a gun-free and safer country.

A similar discourse is seen in Al-Maghour's (2017f) Aliwa The Parrot, where Walid, a young man, is brought up in a loveless home, a home with a mother that clipped her children's wings. 
Walid, symbolically, flew into the darkness and toward the unknown, where he became lost and thus never returned home. Again, Al-Maghour addresses the importance of a mother's role in the lives of her children: She points out that the successes or failures of a person are tied to the successes and failures of their mother. Through this message, Al-Maghour educates women and shows them their vital place in society.

A more powerful image is portrayed in Dried Tomatoes, which tells the story of a business woman from Misurata ${ }^{4}$ who owns an apartment building. One of the neighbors reports to another neighbor, who works in the city's telecom company, the daily activities of residents in the building. The two cause fear among the neighbors, who are suspicious that they are working for the state intelligence agency. Al-Maghour presents the landlord as a quiet lady, steady in her steps, with a strong presence. Upon learning about the men's gossiping, the landlord walks toward them and addresses them with confidence and mockery: "Hey shorty! Why are you bothering [us]?!" The men stutter, and withdraw from the confrontation. Both men quit spying on their neighbors. AlMaghour demonstrates how the small community in the building was liberated by the bravery of a woman. With the country divided by corrupt politicians and militiamen, social ties among individuals, families, tribes, and even cities have weakened. Al-Maghour's two conflicting characters from Misurata work as a metaphor, highlighting that even when men attempt to disrupt peace by sowing conflict, women can bring their communities back together again. Al-Maghour thus emphasizes that women can be great leaders and can bring peace to a divided country.

In the chaotic aftermath of the revolution, reflected by political instability, a lack of jobs, and constant power cuts, Al-Maghour reflects these daily sufferings of Libyan citizens, especially through her female characters. She highlights the great efforts women are making to overcome such obstacles. For example, many of Al-Maghour's female characters have replaced men as the traditional breadwinners: They have taken the jobs of men to provide for their families. As such, they have broken traditional taboos and crossed societal boundaries. The short story The Taxi Driver (Al-Maghour, 2017b) is based on such a narrative. In the story, a widower drives a taxi to make a living, challenging stereotypes as she "hits the gas, [and] drives through the city of militias." Similarly, in The Electric Company (Al-Maghour, 2017a), an outraged mother who is angry with the power outages occuring during the dead of winter expresses her opinions freely and fearlessly: 
"She rolled down the window...spit...and shouted at the top of her lungs 'Damn you electric company, damn you!'”

\section{Peace Offering}

As a women's rights activist and lawyer, Al-Maghour uses her literary platform to address her readers with words of peace in a time of war. She narrates her stories and structures her writings within the frame of nationality and unity. In addition to her vivid descriptions of the city streets and alleys to familiarize readers with the geographical context, Al-Maghour discusses social equality and nationalism in a symbolic yet simple style. In Dried Tomatoes (Al-Maghour, 2016a) all the ladies in the building, despite coming from different backgrounds and cities in Libya, gather around to share a Libyan dish cooked with dried tomatoes for dinner. Dried tomatoes are a major ingredient in most Libyan dishes: They symbolize the values and traditions that all Libyans share. The image of the ladies enjoying dinner together and eating from the same dish at the end of the story brings warmth after a conflict. This positive image is a call for a united Libya, and it is beautifully painted through women's social activities.

In The Afternoon Kids, Al-Maghour (2017c) addresses nationalism through the lens of her childhood. She writes a brief story based on a memory she has of her time in elementary school, as a child in the morning school session. Al-Maghour begins the story by describing how she used to alienate herself from the afternoon session kids thinking they were different. She finally has an encounter with one such "afternoon girl." The girl comforts her while she waits for her father to piock her up from school, and offers her a bite of her sandwich. The two girls engage in conversation and break the barrier that had existe between them. Al-Maghour realizes that the afternoon girl is just like her: They both enjoy recess, dislike homework, and enjoy the same school activities. Al-Maghour uses this short story to demonstrate that despite the divisions within Libyan society that have occurred in the aftermath of the revolution, all Libyans are equal; they share the same joy and pain. She concludes her story with a simple, yet deep, confession:

Then I realized that the "afternoon kids" are the "morning kids," and the "morning kids" are the "afternoon kids"...We all wear the same black uniform, and the same white neck tie, we sit at the same desks under the same roof, we eat the same soaked in olive oil, tuna, and hot sauce sandwiches. (Al-Maghour, 2017c).

\section{Concluding Remarks}


After the start of the Arab Spring, many Libyan writers were focussing on the socioeconomic and political issues in the country. These stories tended to carry a pessimistic tone, reflecting the difficult post-war reality. Within these stories was the narrative of Libyan women as weak and fragile. As Libyan critic Najat Agila (2017) highlighted, there was an emerging phenomena within these post-revolution writings that describe female figures in Libyan literature and film in a negative way. She goes on to urge Libyan writers to give women justice. Al-Maghour's short stories respond to such a call. They break tradition by giving women an authoritative voice in the face of social injustice. Further, Al-Maghour's nationalistic sentiments within many of her stories shed light on hope and the true values that bind Libyans together.

Al-Maghour's short stories stand out in many ways: She takes the lead in discussing sensitive issues in Libyan society, such as rape and sexual abuse. When the government and the media turned a blind eye toward such violence against Libyan women, Al-Maghour tried to give survivors a voice. This voice spoke volumes and broke with old traditions. Her stories emphasize that being a victim of sexual violence and rape is not a crime; the crime is shaming and silencing survivors of such violence. Al-Maghour also distinguishes herself by discussing social struggles in her stories in the hopes of enlightening and educating her readers. She pinpoints the causes of such social ills and tensions with clear criticism and suggests ways to resolve these issues without employing a negative or pessimistic outlook in her stories. Most importantly, Al-Maghour's stories pave the path for future writings to be more honest and open about the social struggles of Libyan society. Her works paves the way for to free and unconditional conversation about these issues, and they make space for the marginalized, especially women, to speak up. Al-Maghour's works after the revolution are not "just" stories: They are a cultural movement calling for positive social change. 


\section{Notes}

${ }^{1}$ Most of her digital publications are on the Libyan website, Al-Mostakbal.

2 This phrase, which literally translates into "you have women," was repeated to the perpetrators by the survivors, as a way of reminding them that they too have women in their families.

${ }^{3}$ A neighborhood in Tripoli that is in the suburbs and intersected between two big neighborhoods, Zawia Addahmani and Anofileen. It falls between the suburbs and the city center, thus connoting imbalance between two parts in the city.

${ }^{4}$ Misruata is a city located in northwestern Libya, approximately $187 \mathrm{~km}$ east of the capital. It was one of the major cities that rebelled against Qaddafi during the revolution. In recent years it has been in political conflict with several other Libyan cities. The city in the story has a sociopolitical connotation in the post revolution context. 


\section{References}

Agila, N. (2017, July 12). صورة المرأة في العطل الدرامي... (روبيك) لغز الحباة [The image of women in drama]. Libya Al-

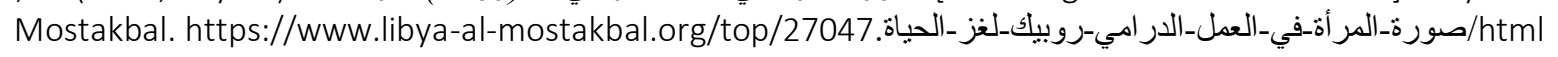
Al-Haddad, F. (2010) Critical studies in Libyan narrative. Dar Alkutub Alwataniya.

Al-Maghour, A. (2015, November 26). قرن الفلفل [Pepper]. Tieob. http://www.tieob.com/archives/13859

Al-Maghour, A. (2016a). Dried tomatoes. Akhbar Libya Al-aan.

Al-Maghour, A. (2016b, December 19). "عام "لأولياي [The city's tale]. Tieob. http://www.tieob.com/archives/17637

Al-Maghour, A. (2017a, January 9). حوش اليتريك [The electric company]. Libya Al-Mostakbal. http://www.libya-al-

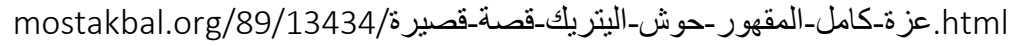

Al-Maghour, A. (2017b, January 1). التاكسيبنتيرة [The taxi driver]. Libya Al-Mostakbal. http://www.libya-al-

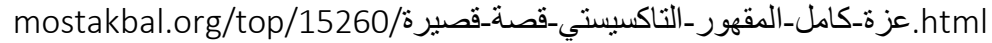

Al-Maghour, A. (2017c, January 26). صنغار العشية [The afternoon kids]. Libya Al-Mostakbal. http://www.libya-al-

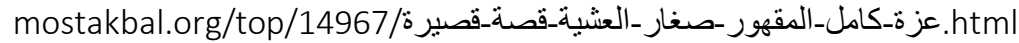

Al-Maghour, A. (2017,d March 7). موجلي وشيرخان [Mowgli and Sheerkhan]. Libya Al-Mostakbal.

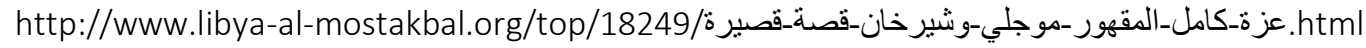

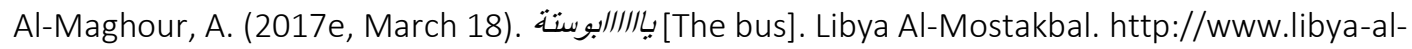

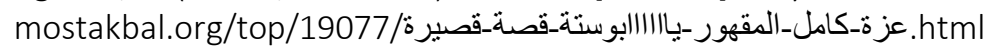

Al-Maghour, A. (2017f, July 15). عليوة البيغاء [Aliwa the parrot]. Libya Al-Mostakbal. https://www.libya-al-

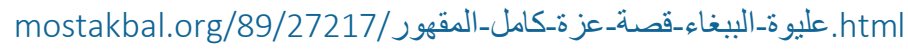

Elnaili, S. (2017). Fighting Oppression with Colors in Libyan Short Story Post The Arab Spring: A Stylistics Analysis of Azza Al-Maghour's Short Stories. Journal of South Asian and Middle Eastern Studies, 40(2), 1828.

Fagih, A. (2008). The Libyan short story: A research anthology. Xlibris.

Gheblawi, G. (2011). Libyan literature: The impact of revolution. Minerva. 